DOI: https://doi.org/10.47405/mjssh.v6i9.1002

\begin{tabular}{|c|c|}
\hline 4.581 & Malaysian Journal of Social Sciences and Humanities (MJSSH) \\
\hline $\begin{array}{l}\text { Malaysian Journal of } \\
\text { Social cciences and }\end{array}$ & Volume 6, Issue 9, September 2021 \\
\hline (MJ-SSH) & e-ISSN : 2504-8562 \\
\hline & $\begin{array}{l}\text { Journal home page: } \\
\text { www.msocialsciences.com }\end{array}$ \\
\hline
\end{tabular}

\title{
Factors Influencing Turnover Intention among Malaysian Unskilled Workers in Oil Palm Plantation
}

\author{
Amran Arifin'1, Humaira Mat Taib', Zaki Aman'1, Abdul Rahman Abdul Rahim² \\ 1'Malaysian Palm Oil Board (MPOB), Bangi, Malaysia \\ 2Universiti Teknologi MARA, AAGBS, Shah Alam, 40000, Malaysia \\ Correspondence: Humaira Mat Taib (humaira@mpob.gov.my)
}

\begin{abstract}
The turn over intention has dramatically caused high turnover among Malaysian unskilled workers in oil palm industry. Therefore, this study was to determine the level of local unskilled workers perception of turnover intention and provide additional insight for the industry players and policy maker to identify the needs and characteristics of the Malaysian employees to them to work in the oil palm plantation in future. This research used quantitative approach and cross- sectional method to address the current scenario in the oil palm plantation. Data were obtained from a field survey of 347 oil palm plantation employees all over Malaysia. A descriptive and cross-tab analysis was used to analyse the data. Findings of the research revealed the workers' demographic characteristics namely age, gender and work tenure have the intention to leave. This research described that majority of respondents $(58.5 \%)$ has intentions to leave from present job to another industry. Finding also found higher salary and allowance and free health service are keys to higher motivations. It was also suggested that employers should provide an attractive benefits package as a strategy to attract and retain workers.
\end{abstract}

Keywords: turnover intention, employees, oil palm plantation, demographics, motivation factors

\section{Introduction}

When a vacancy caused by voluntary or forced, then a new employee to be taken and retrained and this process is called employee turnover (Hussain et al., 2013). Turnover will cause costs to rise when hiring a company re-employment as well as a negative impact on the quality of service or product (Boudreau, 1992). Moreover, Sarminah (2006) revealed that employers will be lost of benefits and friendships due to the loss of workers technical skills and experiences. Predictors of turnover behaviour have historically been the primary focus of the literature (Maertz et al., 2007). Turnover is influenced by several factors that could predict turnover intention (Sarminah, 2006).

Malaysia still depends on the agricultural sector to catalyst economic growth, employment opportunity, and food security. Interestingly, the palm oil industry as contributed RM67 billion for GNI in 2018. However, the increase in oil palm planted area to 5.81 million hectares (Kushairi et al., 2018) has led to the demand of the labor market, particularly the oil palm industry has risen. Subsequently, most oil palm estates face labour shortages especially on Malaysian unskilled workers and the trend is rising every year (Azman, 2014). The utilization of the local unskilled workforce in the palm oil sector is very limited and it has led the country to continue to over dependent on foreign 
workers. In addition, the local worker turnover intention in this sector also high (Zaki et al., 2015). When there is competition for the local workforce, the estate is willing to offer the best deals to attract workers and treat the phenomenon of employee turnover is high among oil palm plantation workers. Turnover among local workers in oil palm plantations can cause terrible effects. Therefore, a study on turnover among local unskilled workers in oil palm sector is vital to determine the level of their tendency to shift to another sector and understand the factors that influence them. The main objectives of this research are to investigate the contribution of demographic and motivation factors on intention to quit among local unskilled employees in oil palm plantation and to determine the turnover intention level among the Malaysian.

\section{Literature Review}

The dependent variable of the study is turnover intention. Meanwhile, demographic and motivation factors were the independent variable in this study.

\section{Turnover intention}

Jacob and Roodt (2007) defined turnover intention as an individual decision making either to remain or quit the organization. Turnover intention is associated to turnover behaviour and roles as an immediate indicator to genuine turnover (Salahudin et al., 2016). Lashley (2000) conceptualizes employee turnover to two groups namely as avoidable and the unavoidable situations. He explains the avoidable situations as little salary, physical difficulty of nature of work, work load, poor administration styles, lacking training support, stress, uncomfortable working environments and transportation insufficient. Meanwhile the unavoidable as pensionable, disability, accident, wedding, delivery leave, further study reasons and others. Moreover, Moore (2000) agreed that worker's intention to leave is a clear signal of the definite quit. This statement supported by Theory Planned behaviour, conceptualize that intention to accomplish a specific attitude is the good predictor of the behaviour (Fishbein and Ajzen, 1975). Although Sauza-Poza (2007) found that only 25\% a turnover intention led to a definite turnover, Price (2001) recommended the turnover intention concept as an option in measuring real turnover. The rates of employee turnover are the essential elements that determine the success of the organizations, the lower rate of turnover will give an advantage to the organization (Akova et al., 2015). Therefore, lower turnover levels are important for organizations in order to continue their operations (Baum, 2006). Thus, it's essential for the institutions to have better retention programs.

\section{Demographic}

Previous studies found that demographic factors are related to turnover intention (William and Hazer, 1986). Luthans et al. (1987) defined the demographic factors namely age, gender, marital status, working experience and education level. Cotton and Tuttle (1986) revealed age, work tenure and income are factors that have a significant relationship with turnover intentions. Meanwhile, Sarminah (2006) found that demographic factors such as gender, age, work tenure are negative and significantly on turnover intention.

Studies by Xu (2008) also depicted that gender has a significant relationship with turnover intention. She conducted her studies among IT staff in Malaysia. Meanwhile, Chong et al. (2013) found that female employee has higher turnover intention among academic staff.

$\mathrm{Ng}$ and Feldman (2013) defined work tenure as a period of times; an individual has been employed by the present organization. Previous studies have determined work tenure is inversely related with turnover (Lewis, 1991). Moreover, Farber (1999) mentioned that fewer tenured workers left more often because they are younger and receive less salary. Instead, if the workers have long work tenured, it's will less inclined to quit the current profession because they incline to be more secure benefits such as in pension schemes that are forfeited on withdrawal (Ippolito, 1987). 
However, there are limited studies investigated the effect of demographics namely, age, gender and work tenure factors on local workers in oil palm plantation turnover intentions. Then demographic factors should be investigated to determine the relationship with the intention to leave by the workers (Akova, 2015). In addition, a good understanding of demographic elements may give a different view in handling workers (David, 2011). Furthermore, previous study results inconsistencies with respect to the factors of turnover intention.

\section{Motivation}

Motivation factor is a vital element at the workplace due to productivity and effects the organization performance. However, each individual has need different motivation (Susan, 2019). Lindner (1998) defined motivation as the inner force that brings individuals to achieve personal and organisation goals. They are several motivation factors studied by past researcher such as job security, freedom, promotions, appreciation of work done, working condition, salary (Zaki et al., 2015; Aarabi et al., 2013; Lindner,1998). Meanwhile, Johnston et al. (1993) posited that promotions are commonly known as wages increases and subsequently affect lessen withdrawals. Moreover, Griffeth et al. (2000) revealed that individual satisfaction will influence them to remain in the organization. In addition, social exchange theory conceptualizes that work satisfaction has an insignificant relationship with worker turnover (Lee and Hong, 2011). Likewise, workers might encourage to voluntarily resigning due to the stressful nature of their work environments. If the workers believe the organizations can't fulfill their needs, they will quit the jobs (Hidayati \& Fadilah, 2015). Specifically, this study focuses on five motivational factors namely, (a) higher salary and allowance, (b) free health service, (c) career development, (d) retirement scheme and (e) working environment. The ranked important of motivational factors of employees at oil palm plantation provide useful information for the palm oil industry in Malaysia. Thus, this study will determine the motivation factors that would influence the workers to remain in the organization.

\section{Methodology}

The dependent variable was the turnover intention and the independent variables were demographics namely age, gender and work tenured and motivation factors. The study was conducted in oil palm estates throughout Malaysia and restricted to unskilled local workers.

Unskilled workers are defined as an individual who is employed in an oil palm plantation as a general worker, harvester, checker, weeded and driver. There were 66,312 locals who are working in the oil palm plantations at various job levels throughout Malaysia. The research instruments were modified and adopted from Siti Fardiana (2004), Yim et al. (2014) and Christina (2012). This study used a fivepoint Likert scale ( $1=$ 'strongly disagree' to $5=$ 'strongly agree') to assess all items. Descriptive, frequency, and cross-tab analysis was employed in this study. Managers of all oil palm estates were contacted via email regarding this study to seek voluntary participations from their employees. Questionnaires were distributed to the respondent in small groups to be completed during works hours and were returned directly to the enumerator. The response rate is $86 \%$ (347 out of 403) and the sample size is acceptable (Sekaran \& Bougie, 2013). This research examined the ranked importance of motivational factors of employees at oil palm plantation.

\section{Results}

\section{Demographic Profile}

Three demography factors which could have influenced individuals to turn to other sectors, namely, gender, age and work tenure were investigated. The result shows the level of the tendency of unskilled workers to turnover within the next six months. 
DOI: https://doi.org/10.47405/mjssh.v6i9.1002

Table 1: Crosstabulation between Gender and Turnover Intention

\begin{tabular}{cllll}
\hline \multirow{2}{*}{ Demographic } & & \multicolumn{2}{l}{ Turnover Intention Categories } & Total \\
\cline { 3 - 4 } & & Yes & No & \\
\hline \multirow{2}{*}{ Gender } & Male & 155 & 95 & $250(72 \%)$ \\
& Female & 48 & 49 & $97(28 \%)$ \\
& Total & $203(58.5 \%)$ & 144 & $347(100 \%)$ \\
\hline
\end{tabular}

Table 1, which demonstrated the respondent's gender. Male employees represented $72 \%$ and women constituted $28 \%$. The uneven composition between the genders is due to the lack of suitable jobs for women. Moreover, this oil palm industry is more suitable for men because of the 3D (dirty, dangerous, difficulty) perception (Zaki et al., 2015). The results show that a total of 155 male employees (62\%) out of 250 male workers and a total of 48 female employees (49.5\%) out of 97 female workers had the intention to shift to other sectors. The total number of respondents who had the tendency to leave is $58.5 \%$.

Table 2 shown the distribution of the age group and categorized into five groups: 18-25 years age group (22.2\%), 26-35 group (25.4\%), age group 36-45 (27.6\%), age group 46-55 (20.5\%) and age group more than 56 years was $4.4 \%$. The aged group of workers range 18 to 25 years had a high tendency to change jobs, which were as many as 59 people or $76.6 \%$, followed by the age group of 26 - 35 years with a total of 61 respondents $(69.3 \%)$. The age groups of $36-45,46-55$, and those older than 56 totalled $50(52.2 \%), 27(38 \%)$, and $6(40 \%)$, respectively.

Table 2: Crosstabulation between Age and Turnover intention

\begin{tabular}{lllll}
\hline \multirow{2}{*}{ Demographic } & & \multicolumn{2}{l}{ Turnover Intention Categories } & Total \\
\cline { 3 - 4 } & & Yes & No & \\
\hline \multirow{4}{*}{ Age } & $18-25$ & $59(76.6 \%)$ & 18 & $77(22.2 \%)$ \\
& $26-35$ & $61(69.3 \%)$ & 27 & $88(25.4 \%)$ \\
& $36-45$ & $50(52.2 \%)$ & 46 & $96(27.5 \%)$ \\
& $46-55$ & $27(38 \%)$ & 44 & $71(20.5 \%)$ \\
& $>56$ & $6(40 \%)$ & 9 & $15(4.4 \%)$ \\
& Total & 203 & 144 & $347(100 \%)$ \\
\hline
\end{tabular}

Table 3, illustrated the work tenure of the respondent and grouped into five categories, which are less than one year $(12.4 \%)$, one to five years $(42.6 \%)$, six to ten years $(21.9 \%), 11$ to 15 years $(7.8 \%)$ and group more than 16 years was $15.3 \%$. The results indicated the group of work tenure less than one year had a high intention to quit jobs, which were as many as 31 respondents or $72 \%$, followed by those in the group of 1-5 years with a total of 90 employees (60\%). The groups of 6-10, 11-15, and those are works more than 16 years totalled $40(52 \%), 16(59 \%)$, and $26(60 \%)$, respectively.

Table 3: Crosstabulation between Work tenure and turnover intention

\begin{tabular}{lllll}
\hline \multirow{2}{*}{ Demographic } & & \multicolumn{2}{l}{ Turnover Intention categories } & Total \\
\cline { 3 - 4 } & & Yes & No & \\
\hline \multirow{3}{*}{ Work Tenure } & $31(72 \%)$ & 12 & $43(12.4 \%)$ \\
& 1-5 year & $90(60 \%)$ & 58 & $148(42.6 \%)$ \\
& 6-10 year & $40(52 \%)$ & 36 & $76(21.9 \%)$ \\
& 11-15 year & $16(59 \%)$ & 11 & $27(7.8 \%)$ \\
& $>16$ year & $26(60 \%)$ & 27 & $53(15.3 \%)$ \\
& Total & 203 & 144 & 347 \\
\hline
\end{tabular}




\section{Motivation Factors}

A total of five motivation factors items which may have influenced respondents to work in this sector were identified, and are listed in order of priority of their needs in Table 4. Respondents measured their level agreement on a five- point Likert scale ranging $1=$ 'strongly disagree' to $5=$ 'strongly agree'. Table 4, it was identified that respondents rated the higher salary and allowances as the main reason that influence them to be in this industry, followed by free health service, career development and retirement scheme. However, they are not scarified with the working environment.

Table 4: Motivation factors

\begin{tabular}{llll}
\hline Items & Mean & Standard Deviation & Ranking \\
\hline Higher Salary and allowance & 4.32 & 0.834 & 1 \\
Free health service & 4.19 & 0.877 & 2 \\
Career development & 4.06 & 0.845 & 3 \\
Retirement scheme & 4.05 & 1.129 & 4 \\
Working environment & 2.62 & 1.153 & 5 \\
\hline
\end{tabular}

\section{Discussion}

The number of male respondents was $80 \%$, while female respondents constituted $20 \%$. The results showed that majority of respondents $58.5 \%$ have the to quit from the current employer. Most of them are male, young generation and new recruitment.

The finding demonstrated male respondents have higher turnover intention compare the female employees. The inclination to shift jobs was high among male workers, whereby about $62 \%$ intended to do so in the future and female $49.5 \%$. This result contradicts from the past studies. Chen and Francesco (2000) have conducted a study in China that found female employees are less committed to the organization and have a higher intention to quit compared to male employees. The male respondents have intent to leave, may due they assumed that working in oil palm plantation in long run, they will not achieve the expectation goals.

The age factor had a significant impact on the respondent in regards to changing jobs. The finding revealed that $71.3 \%$ intended to move the work is Y Generation, which aged between 18 years to 35 years. In other words, the younger they are, the higher their intention to leave the oil palm industry. This finding similar to Kabungaidze and Mahlatshana (2013) which revealed that young teacher is willing more to "job hop" to other sectors. Interestingly, the results demonstrated the respondent's intentions to quit are lower when they are older. This statement supported by Lewis (1991) that found young individuals have high turnover, but continuously declines as employee aged. Another reason, they are still young and need to develop them to have a better livelihood.

The results indicated that respondents with shorter tenure has higher intention turnover compared with respondent with longer tenure. Interestingly, this finding similar to Lim (2001), who found that Malaysian employees was active job hopper within three years after they attached with the organization. In similar notes, Hokanson et al. (2011) revealed that the $\mathrm{X}$ and $\mathrm{Y}$ generation have an average of three years of employment tenure. In addition, Maden (2014) mentioned the long-tenured workers are keen to stay in the organization due to the benefits and compensation provided by the organization to increase worker length of tenure, employers should have retention policies that provide the employee with the vast prospect to continue working with the organization such as recompense the employee's good performance. This strategy has been proven by past scholars.

The results shown that the motivation factors influencing their decisions to remain working in the oil palm plantation were, in order of priority is to get (1) high salary and allowance, (2) the organization need to provide free health services, (3) career development, (4) retirement scheme and lastly (5) working environment. The results demonstrated that motivation factors such as high salary and 
allowance, provide free health service, career development and retirement scheme are encouraging factors for the workers to remain with an organization. This statement supported by Bouckenooghe et al. (2013) who agreed that rewarding system such as pay for performance could retain the employee with the organization. In similar notes, Menefee and Murphy (2004) and Nazirah et al. (2019) mentioned that several factors such as good salary, job satisfaction, promotion opportunities, satisfaction with benefits, and feel satisfied with the working environment would led them to remain in organization. However, to overcome the challenge in the working environment, the organization needs to create a culture such as relationship, recognition, involvement and communication in which individuals are motivated by their work.

\section{Conclusion}

It has been confirmed in this study which has investigated the effects of the demographic factors and motivation factors of the employees in oil palm plantation towards turnover intentions. The intention to quit among workers are high due to the fact that there are a lot of opportunities being offered by other industries such as services, manufacturing's, constructions and etc. In addition, the key reasons for quit are due to achieved their needs and looking for better livelihood.

To conclude, the findings of this research would assist the policy marker, managers to revise program and strategies to overcome turnover issue among the local workers in oil palm plantation as well as to ensure higher productivity, low cost of production and effectiveness in the organization. The key element to enhance the motivation is provides the variety and quality of training options to the employees. Moreover, organization must find innovative ways to keep their employees motivated. This study is limited to several factors that encouragement turnover among the local workers. Thus, in any future study, it is suggested that the education factors, location could influence workers' tendencies to move to other sectors to be examined. This finding is important to reduce high workers turnover in this sector.

\section{References}

Aarabi, M. S., Subramaniam, I. D., and Akeel, A. B. A. A. B. (2017). Relationship between motivational factors and Job performance of employees in Malaysia service industry. Asian social Science, 9(9), 301-310.

Akova, O., Gurel Cetin, G. and Ibrahim Cifcic, I., (2015). The relation between demographic factors and the turnover intention in pre-opening hotel businesses. Procedia - Social and Behavioral Sciences, 207: 377 - 384 .

Azman, I. (2014). The effect of labour shortage in the supply and demand of palm oil in Malaysia. Oil Palm Industry Economic Journal, 13(2): 15-26.

Aziz, M. (2004), Role stress among women in the Indian information technology sector. Women in Management Review, 19(7), 356-363.

Baum, T. (2006). Human resource management for the tourism, hospitality and leisure: An international perspective. London: Delmar Thomson Learning.

Boles, J. S., Ross, L., and Johnson, J. (1995). Reducing employee turnover through the use of preemployment application demographics: An exploratory study. Journal of Hospitality \& Tourism Research (19): 19-30.

Bouckenooghe, D., Raja, U. and Butt, A. N. (2013). Combined effects of positive and negative affectivity and job satisfaction on job performance and turnover intentions. The Journal of Psychology, 147(2): 105-123.

Boudreau, J. W. (1992). Utility analysis for decisions in human resource management. In M. D. Dunnette \& L. M. Hough (Eds.), Handbook of industrial and organizational psychology (2nd ed., Vol. 2, pp. 621-745). Palo Alto, CA: Consulting Psychologists Press

Christina, L. K. (2012). What factors attract and motivate dairy farm employees in their daily work? Journal of Prevention, Assessment and Rehabilitation, 41(1): 5311-5316. 
Chen, Z. X., and Francesco, A. M. (2000). Employee demography, organizational commitment, and turnover intentions in China: Do cultural differences matter? Human Relations, 53(6), 869-887.

Choong,Y, O., Keh,C, G.,Tan,Y,T., Chun-Eng Tan,C,E (2013). Impacts of demographic antecedents toward turnover intention amongst academic staff in Malaysian Private Universities. Australian Journal of Basic and Applied Sciences, 7(6): 46-54.

Cohen, G., Blake, R. S., and Goodman, D. (2015). Does turnover intention matter? Evaluating the usefulness of turnover intention rate as a predictor of actual turnover rate. Review of Public Personnel Administration, 26(3): 1 -24.

Cotton, J. and Tuttle, J. (1986). Employee turnover: A meta-analysis and review with implication for research. Academy of Management Review, 11(1): 55-70.

David, F. R. (2011). Strategic management: Concept and cases. New Jersey: Pearson Education.

Dodd-McCue, D. and Wright, G. (1996). Men, women, and attitudinal commitment: The effects of workplace experiences and socialization. Human Relations, 49: 1065-1091.

Farber, H. S., (1999), Mobility and stability: The dynamics of job change in labor markets in Henry S. Farber (eds.), Handbook of Labor Economics, vol 3, Part B, Elsevier.

Fielden, S. L., and Davidson, M. J, (2001). Stress and gender in unemployed female and male managers. Applied Psychology, 50(2): 305-334.

Fishbein, M. and Ajzen, I. (1975). Belief, attitude, intention and behavior: An introduction to theory and research. Reading, MA: Addison Wesley.

Gianakos, I. (2001). Predictors of career decision-making self-efficacy. Journal of Career Assessment, 9(2): 101-114.

Griffeth, R. W., Hom, P. W. and Gaertner, S. (2000). A meta-analysis of antecedents and correlates of employee turnover: Update, moderator tests, and research implications for the next millennium. Journal of Management, 26: 463-488.

Hayes, T. M. (2015). Demographic characteristics predicting employee turnover intentions. Walden University. Phd Thesis.

Hidayati, A. and Fadilah, P. (2015). Determinants of turnover intention among employees. Journal of Administrative, 12(2): 1-12.

Hokanson, C., Sosa-Fey, J., \& Vinaja, R. (2011). Mitigating the loss of knowledge resulting from the attrition of younger generation employees. International Journal of Business \& Public Administration, 8, 138-151.

Hussain, I. A., Yunus, N., Ishak, N. A., and Daud, N. (2013). The influence of intention to leave towards employee engagement among young bankers in Malaysia. International Journal of Business and Management, 8(14); 89 -97.

Ippolito, R. A. (1987). Why federal workers don't quit. Journal of Human Resources, 22, 281-299.

Jacobs, E. and Roodt, G. (2007). The development of a knowledge sharing construct to predict turnover intentions. Aslib Proceedings: News Information Perspectives 59(3): 229-248.

Johnston, M. W., Griffeth, R. W., Burton, S., and Carson, P. P. (1993). An exploratory investigation into the relationships between promotion and turnover: A quasi-experimental longitudinal study. Journal of Management, 19: 33-49.

Kabungaidze, T. and Mahlatshana, N. (2013). The impact of job satisfaction and some demographic variables on employee turnover intentions. International Journal of Business Administration, $4(1), 54-65$.

Kushairi, A., Loh, S, K., Azman, I., Hishamuddin, E., Melina Ong, A., Izuddin, Z. B. M. N., Razmah, G.,

Shamala, S. and Ahmad Parveez, G. K. (2018). Oil palm economic performance in Malaysia and R\&D Progess in 2017. Journal of Oil Palm Research, 30(2): 163-195.

Lashley, C. (2000). Hospitality retail management: A unit manager's handbook: Butterworth Heinemann, Oxford.

Lee, S. Y., and Hong, J. H. (2011). Does family-friendly policy matter? Testing its impact on turnover and performance. Public Administration Review, 71, 870-879.

Lee, S. Y. and Whitford, A. B. (2007). Exit, voice, loyalty, and pay: Evidence from the public workforce. Journal of Public Administration Research and Theory, 18: 647-671.

Lewis, G. B. (1991). Turnover and the quiet crisis in the federal civil service. Public Administration Review, 51: 145-155. 
Lim, I. (2001). Work Cultural values of Malays and Chinese Malaysian. International of Cross Cultural Management, 2(2): 209-226.

Lindner, J. R. (1998). Understanding Employee Motivation. The Journal of Extension, 36(3): 1-8.

Luthans, F., Baack, D. and Taylor, L. (1987). Organizational commitment: Analysis of antecedents. Human Relations, 4: 219-236.

Maden, C. (2014). Impact of fit, involvement, and tenure on job satisfaction and turnover intention. The Service Industries Journal, 34(14): 1113-1133.

Maertz, C. P., Griffeth, R. W., Campbell, N. S. and Allen, D. G. (2007). The effect of perceived organizational support and perceived superior support on employee turnover. Journal of Organizational Behaviour, 28(8): 1059-1075.

Menefee, J. A., and Murphy, R. O. (2004). Rewarding and retaining the best: Compensation strategies for top performers. Benefits Quarterly, 20: 13-20.

Moore, J. E. (2000). One road to turnover: An examination of work exhaustion in technology professionals. Management Information Systems Quarterly, 24(1): 141-168.

Nazirah, C. J., Norsida, M., Alaudin, A. L., Zaki, A., and Ramle, M. (2019). Relationships between job satisfaction and job factors among extension agents in the Malaysia's oil palm industry. Oil Palm Industry Economic Journal, 19(1): 30-36.

NG, T., W, H., AND FELDMAN, D, C. (2013). Does Longer Job Tenure Help Or Hinder Job Performance? Journal Of Vocational Behavior, 83 (30): 305-314.

Pallant, J. A. (2011). Step by step guide to data analysis using IBM SPSS. 5th edition McGraw-Hill Education.

Porter, L. W. and Steers, R. M. (1973). Organizational, work, and personal factors in employee turnover and absenteeism. Psychological Bulletin, 80: 151-176.

Price, J., (2001). Reflections on the determinants of voluntary turnover. International Journal of Manpower, 22(7): 600-624.

Salahudin, S. N., Alwi, M. N. R., Sarah, S. B. and Idayu, N. A. (2016). Generation Y: Organizational commitment and turnover intention. The European Proceedings of Social \& Behaviour Sciences: $449-456$.

Sarminah, S. (2006). The contribution of demographic variables: Job characteristics and job satisfaction on turnover intention. Journal of International Management Studies, 1(1): 1-12.

Sousa- Poza, A. (2007). The effect of Job satisfaction on labour turnover by gender. An analysis for Switzerland. The Journal of Socio-economic, 36: 895-913.

Sekaran, U., and Bougie. (2013). Research methods for Business. A skill Building Approach. 5th Edition John Wiley \& Sons Ltd.

Spector, P. E. (1985). Measurement of human service staff satisfaction: Development of the job satisfaction survey. American Journal of Community Psychology, 13, 693-713.

Siti Fardaniah, A, A. (2004). Hubungan Kualiti kehidupan Bekerja dengan Kecenderungan Pusing Ganti Pekerja: Kajian Tinjauan ke atas Operator Pengeluaran di Kilang Celestica, Johor. Msc Thesis.

Susan, M., H. (2019). 8 ideas on how to inspire motivation in the workplace. Human Resources.

Szamosi, L. T. (2006). Just what are tomorrow's SME employees looking for? Education + Training, 48(8/9): 654-665.

William, L. J. and Hazer, J. T. (1986). Antecedents and consequences of satisfaction and commitment in turnover models: A re-analysis using latent variable structural equation methods. Journal of Applied Psychology, 71: 219-231.

$\mathrm{Xu}$, Y. J. (2008). Gender disparity in STEM disciplines: A study of faculty attrition and turnover intentions. Research in Higher Education, 49(7): 607-624.

Yim, K. P. W., Wong, I. A., Weng, H. K. (2014). Student career prospect and industry commitment: The roles of industry attitude, perceived social status, and salary expectations. Journal of Tourism Management, 40: 1-14.

Zaki, A., Abdul Rahman A. R. and Ahmad Kushairi, D. (2015). Generation Y perceptions of employment in the plantation sector. International Journal of Recent of Advances in Organization Behaviour and Decisions Sciences, 1(4): 605-616. 